\title{
Renewing Terraces and Drystone Walls of Algarvian Barrocal. Cultural and Touristic Values
}

\author{
Marta Marçal Gonçalves ${ }^{\text {(10000-0002-0887-7734] }}$, Gonçalo Prates ${ }^{123[0000-0001-5797-9158]}$ and \\ Stefan Rosendahl ${ }^{45[0000-0002-3553-8885]}$ \\ ${ }^{1}$ Universidade do Algarve, Campus da Penha, 8005-139 Faro, Portugal \\ ${ }^{2}$ Centro de Estudos Geográficos, IGOT, Universidade de Lisboa, Lisboa, Portugal \\ ${ }^{3}$ Laboratorio de Astronomía, Geodesia y Cartografía, Universidad de Cádiz, Cádiz, Spain \\ ${ }^{4}$ Universidade Lusófona de Humanidades e Tecnologias, Campo Grande 376, 1749-024 Lis- \\ boa, Portugal \\ mgoncaleualg.pt
}

\begin{abstract}
This paper aims to enhance the functions of terraces and drystone walls as structural elements and distinctive factors of the traditional rural zone known as the barrocal of the Algarve, south of Portugal. In fact, such elements define the character of the landscape that forms the background of a traditional touristic region along the coast. The core of this paper will be the knowledge of construction processes, spatial distribution, and hydrological, ecological, economic and social functions, once it is quite necessary for the Algarve region. Some projects and studies have been developed in the Mediterranean context, but there is not enough research on this subject in the south of Portugal. Secondly, the social meaning, or acknowledgement of the landscape characterized by drystone wall structures, will be the key for finding real possibilities of renewing the terraces. Therefore, the landscape will be assumed as a common good. In this subject, we take into account the potential role and sensibility of tourists and resident population. Beyond static patrimonial statutes, we can design some practical possibilities to enhance plastic features and new uses leading to an acknowledgement of the Algarvian drystone wall structure, referred as a part of Mediterranean coastal landscapes. Some examples that can add cultural and touristic value could be: recreation areas for urbanites, new cooperative forms of agriculture, hobby farming, workshops about harvesting traditional products, circuits and pedestrian paths, and interchange with similar Mediterranean regions defining broader circuits.
\end{abstract}

Keywords: Drystone Walls, Heritage, Algarve, Portugal.

\section{$1 \quad$ Introduction}

\subsection{Framework}

Terraces are typical of the Mediterranean basin, with dry farming, forming cultural landscapes. They are artificial slopes, appearing as a form of adaptation to sharp natural slopes and requiring careful maintenance because of, for example, the minimization of 
uncontrolled water action after a rainfall, which often causes soil erosion phenomena [1].

Drystone constructions are also typical of the Algarvian barrocal. At present, these are practically abandoned, which encourages their degradation. If new functions and uses were given to them, its consequent use would lead to its maintenance and preservation.

Barrocal means exactly clay (barro, in Portuguese and Spanish) and lime (cal, idem). It means, in real terms, a fine layer of clayish soil -mostly 10 to $20 \mathrm{~cm}$ of clay over an extensive mass of lime rock. In the past, a karstic process took place forming big aquifers with various depths, normally reaching hundreds of meters [2].

Terraces form a landscape that is a real proof of the interactions between man and the environment that surrounds him, and as such must be preserved. There are even landscapes of this type classified as World Heritage by UNESCO, as is the case of Alto Douro Vinhateiro, in Portugal.

Forming an heritage, it plays a very important role, helping to define our sense of belonging, our identity, our character and our image [3, 4] and, when their intrinsic values are valued, the bonds it establishes between our past, present and future are also valued [5]. However, these landscapes lose their identity and aesthetic value when they fail to perform the functions for which they were created $[1,6]$.

Terraces promote new economies, contributing, at an ecological level, to a greater infiltration of water in the soil, reducing water erosion, avoiding the loss of the vegetal layer and preserving the majority of the nutrients (ibidem). Being a man-made construction, its social valorization is of the first stages in its renewal, so that its maintenance is made from the populations, with an active participation.

These cultural landscapes have played a key role and, in order to combat their disappearance and degradation, a number of projects have been created and implemented for their recovery, namely a pilot project in the Serra da Tramuntana (Majorca, Spain) to train young people in the art of building in drystone [7]; the HERCULE project which lasted for three years, with the participation of Portugal, France, Austria and Switzerland, teaching the techniques of building the walls [8]; the TERRISC project involving Spain, France and Portugal from the SUDOE region, proposing the revaluation of these spaces for their functions of risk prevention and water resources management, including their cultural and landscape values [9]; the PATTER project for the cataloging of heritage linked to drystone walls $[10,11]$; the project ALPTER, to counteract the abandonment of terraced agricultural areas in the alpine region [12] and the PROSIT project, for the maintenance of the terraces of the Cinque Terre, Liguria, Italy [13].

These projects have an economic aspect, in order to create jobs, to promote tourism development, presenting an heritage aspect, in the sense of valuing it by artisans and populations and an environmental aspect due to its importance in this area [7], which has already been mentioned.

Once the renovation is started, it becomes feasible to use it for tourism, such as nature tourism, rural tourism or cultural tourism, with the consequent economic viability of the same [1]. In this context, tourism, being a cross-cutting activity, combines dynamically endogenous and exogenous resources, that can result in social, economic and 
environmental gains [14]. It appears to be a privileged vehicle, since it can cover a wider spectrum of people, helping to safeguard and preserve this heritage by its use.

Algarve is today the second Portuguese region with more revenues due to tourist activity [15], being the tourism sector the biggest booster of the local economy.

Since works on the survey and cataloging of drystone walls structures in this area of Portugal is rare, this article intends to give a general overview of this problem and the potential they have, both in social, or in heritage and tourism terms.

Another objective of this paper is to enhance the functions of terraces and drystone walls as structural elements and distinctive factors of the traditional rural area known as the barrocal of the Algarve, in the south of Portugal, and to draw attention to a type of heritage that can be recovered and valued.

\subsection{Geographic Overview of the Algarve}

The Algarve region, in the south of Portugal, can be divided in three sub-regions [16], p. 21: Alto Algarve (High Algarve), Algarve Calcário (Limestone Algarve) and Baixo Algarve (Low Algarve).

The Alto Algarve corresponds to the outcrop of folded carboniferous shales, whose morphology was described by Lautensach [17] as an agglomeration of molehills, which reaches nearly $600 \mathrm{~m}$ in the Serra do Caldeirão. The highest mountain is Foia in the Serra de Monchique, with $902 \mathrm{~m}$, built up by nephelinic syenite rocks.

In the Algarve Calcário predominate Jurassic limestones and marls, forming hills with heights up to about $400 \mathrm{~m}$. The Barrocal region in central and eastern Algarve belongs to this division. Finally, Baixo Algarve is constituted by the coastal plain, mainly built up by tertiary and quaternary sediments - Fig. 1 - where the pilot zone, which will be mentioned later, is shown.

Due to geomorphological and climate features, the vegetation cover, and even people's traditions, a strong Mediterranean influence can be felt in Algarve [18], although the region is located in the west of the Strait of Gibraltar, outside the actual Mediterranean basin.

One of the characteristics of the Mediterranean region is the presence of mountains. Although the Algarve hills are not as impressive as other mountains in the Mediterranean basin, they build up a scenery which can be seen from the coastline. These hills safeguard the lower Algarve regions from the cold north winds and protect parts of the barrocal and littoral areas with their smoother Mediterranean climate, which extends from the actual Mediterranean basin to the west up to the south of Portugal.

The vegetation cover of Algarve corresponds in a large part to the Mediterranean flora. The fig, carob, and almond trees can be found here and in the Mediterranean basin, supporting the "Mediterranean Diet", an alimentation based on local products including olive oil, bread and wine.

The barrocal region belongs to a part of Algarve Calcário and is characterized by its limestone hills, reddish soil (terra rossa) and Mediterranean climate. Typical is an agriculture which is developed in terraces, where unirrigated orchard trees, mainly fig, carob and almond trees, are cultivated [19]. Around the trees, leguminous crops, such as beans and peas, are planted to allow the nitrification of the soil. Leaves of fig and 
carob trees are fed to livestock (ibidem). Thus, the traditional unirrigated agriculture system fulfills a lot of ecological functions.

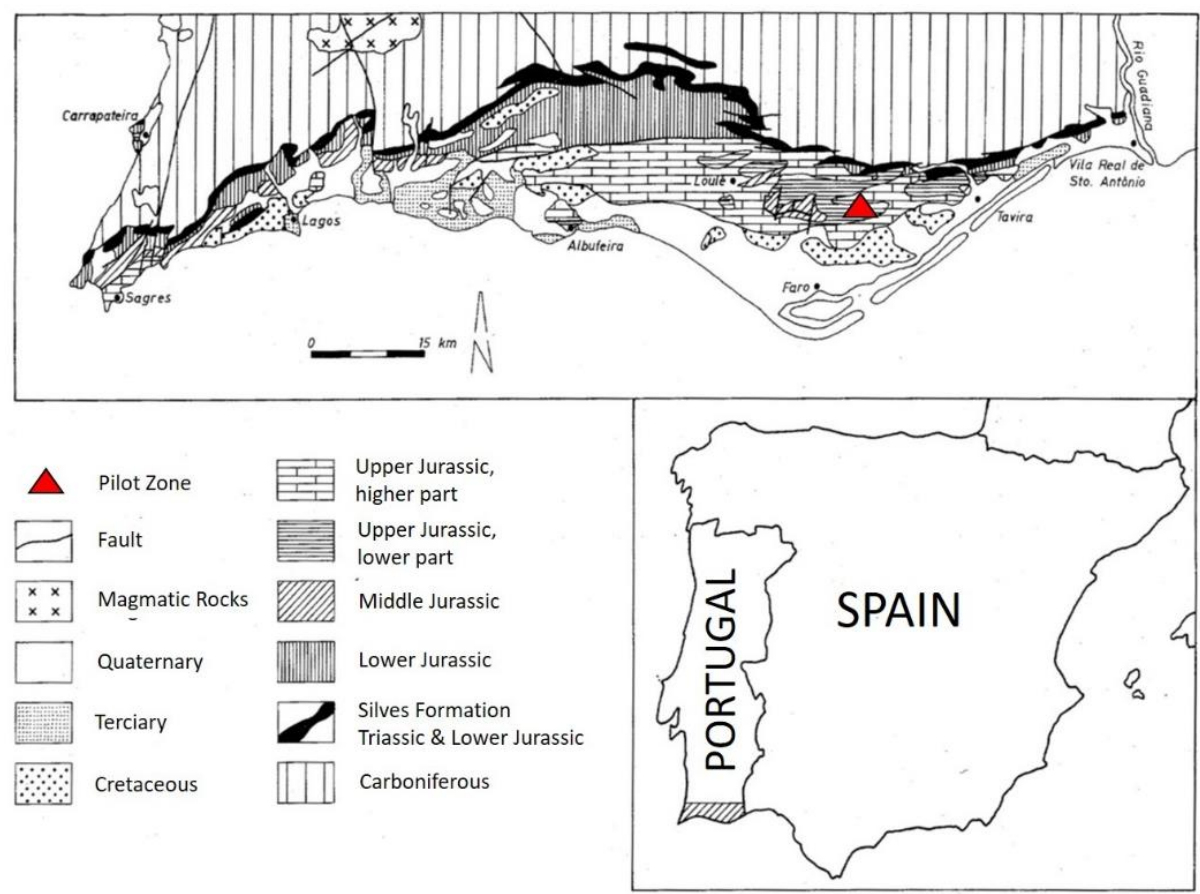

Fig. 1. Geological map of Algarve, showing the pilot zone (source: Rosendahl [20])

On the other side, the introduction of irrigated agricultures, as practiced mainly in Baixo Algarve, originated various ecological problems. First, the transformation of dryland in irrigated fields induced the abandonment of the traditional unirrigated terraces. Second, in the Jurassic limestone karst of Barrocal, a complex aquifer system has developed which supplied water for urban use until the end of the 1990's. After the year 2000, this kind of water supply has been substituted by a system of dams, increasing the eutrophication risk. From then on, underground water was used more and more intensively for the irrigation of fields.

The increase of groundwater extraction for irrigation, financed by the EU, accelerated the degradation of groundwater quality, because salty sea water could intrude into the freshwater aquifer system [2, 21]. On the other hand, the use of groundwater for irrigation combined with evaporation on the field, led to salinization of soils. The sealing of the ground caused by edifications and streets avoided the recharge of the aquifer with fresh water in large areas, increasing the concentration of salt in the groundwater in the littoral area. 


\subsection{Methodology}

It is recurrent, in this type of work, the use of bibliographical, digital and cartographic publications, whether scientific or general, that address the subject studied.

The comparison with other existing examples in other geographical areas and the exchange of experience is fundamental for the analysis of the approach carried out, which is why personal contacts have been made to exchange experiences.

Alongside, field visits, photographic records, photogrammetric surveys and various annotations were made with the aim of understanding, describing and characterizing the object of study. In this field of investigation, one can only create new knowledge about a subject, covering the study zone, observing phenomena and performing surveys [22]. It is the so-called qualitative method, presupposing a description of the observed events from the point of view of the approach and only those that are relevant to achieve the objective (ibidem).

In the collection of data directly from the studied object empirical methods were applied, requiring only that the concrete elements existing in the territory are observed and investigated (ibidem); in the case of the study zone, these data are accessible at any time.

\section{Cultural and Touristic Values of Drystone Walls}

It seems to be only in situations of threat that value is attributed to the heritage. This is certainly the case of the vernacular heritage, where drystone buildings are included.

The concept of heritage has evolved in recent years and continues to evolve [23, 24]: it went from an elitist concept of an isolated historical monument that identified heritage with culture, limiting its meaning to historical heritage [25], to an integral and broader approach [23, 24], composed of cultural and/or natural assets. The concept extended also to objects that were not initially part of the concept adopted, giving them the heritage status (ibidem). Nowadays, heritage is also considered as an identity's resource, a territorial legacy and an economic asset for development [25], becoming a place of memory.

One of the consequences of the 1999 Australian ICOMOS Burra Charter [26] was the fact that the conservation of heritage assets was no longer based on the intrinsic quality of the object, but took into account the capacity of society to recognize its values, on which their cultural identity can be constructed, while simultaneously considering the tangible and intangible values of the objects to be studied [24].

A major impetus in opening up the concept of heritage came also with the 1999 Charter of the Vernacular Heritage [27], which is an emerging patrimony. This Charter opens the way for the so-called "smaller heritage" to take its place.

With the new paradigms that have been placed on society, local participation in decision-making processes, supported by the Faro Convention of 2005 [28], is becoming more important. This Convention only reinforces the idea that heritage is a social will, without which it does not exist; the vernacular heritage, in particular, is the physical testimony of many years of human labor, to mold and dominate the environment for its benefit. 
The steep slopes that occur in some territories, such as the Algarvian barrocal, forced the man to adapt himself to the environment, building terraces to be able to practice agriculture, facilitating the settlement of the population and exhibiting the interaction of man with nature. The walls and terraces are a way of "taming the territory" and "arrange the stone", according to Carvalho [29].

The terraces and drystone walls form an integral part of the agricultural activity, being typical of the Mediterranean climate, where there was traditionally dryland farming. In the territory under study, there are still plenty of them, despite their abandonment and the consequent lack of maintenance. As they are no longer able to fulfill their functions, landslips and landslides increase $[1,6,10]$.

Vernacular heritage is the most difficult type of heritage to recognize as such, and therefore to preserve, for having been even recently considered as a minor heritage.

One of the reasons for this to happen, is that it "is always there" [3], consists mainly of elements of everyday life and often has a negative connotation related to poverty and the difficulties of the past.

However, this "small" heritage is precisely the one that gives rise to more identification with the place and the identification of people with their roots and their land. It is the main definer of genius loci and the cultural identity of each community.

Apparently, they are simple elements, without major importance, but when one begins to study and investigate techniques, location, their constructive characteristics, why they are so, this heritage has an inherent complexity, whether in the handling, both in design and in construction, which would not be expected in a "smaller heritage".

In the case of drystone constructions, meaning stones heaped together without a binder, at first sight and for the less attentive observer, the stones appear randomly arranged, either on the wall or these on the territory; however, the permanence of these constructions reveals, on the part of the constructor, a sense of balance and art in the masonry assembly, which is not simple at all [30].

At the tourist level, this structure of walls holds great potential.

The fact that they are generally abandoned is related to the loss of use of the fields and also to cultural devaluation. When real possibilities of renovation of the terraces are discovered, defining new uses, these can be reborn, like new cooperative forms of agriculture, which could increase the local economy.

Since landscape and built heritage are common property, they must be managed in an integrated way, enhancing the role and sensitivity of tourists and residents. In the latter case, taking advantage of their sense of identity, this will be the way to go. For this to happen, heritage must be explained and its social, cultural, environmental and economic importance must be conveyed and enhanced.

With tourism, it is possible to highlight and transmit the cultural heritage that is available. Proposals for tourist activities, such as recreation areas for urbanites, hobby farming, workshops about harvesting traditional products, circuits and pedestrian paths, interchange with similar Mediterranean regions defining broader circuits, among others, could make this heritage much more attractive from the tourist point of view.

These measures are intended to revive a heritage that is currently in decline, making it economically viable, creating an alternative option for beach tourism and simultaneously making it popular. 
To achieve these purposes, the renovation and rehabilitation of the walls is necessary. At first, this preservation and maintenance must be done by local populations, taking advantage of their sense of place and identity. The use of tourism is one of the possibilities that opens up and, from the outset, seems to be a very interesting solution in the Algarve, a region that depends mainly on the tourism sector. This would be another possible proposal to include into the current touristic offer, and can be enjoyed practically all year round.

Another way to rehabilitate these walls - which are private property - is to hold workshops, as is done at the Fundació el Solà in Fatarella, Catalonia: permission is requested from the owners of the walls to work on them, and the workshop, which is paid by the participants, consist in the restoration of these walls. Thus, money can be paid to the teacher (mestre), who organizes has some return of the investment, who participated learned more on the subject and the owner of the wall has the wall restored.

In this particular case of Algarvian barrocal, we start from a pilot zone, near the hill of S. Miguel (Fig. 2), representative of what can be found in the Algarvian barrocal.

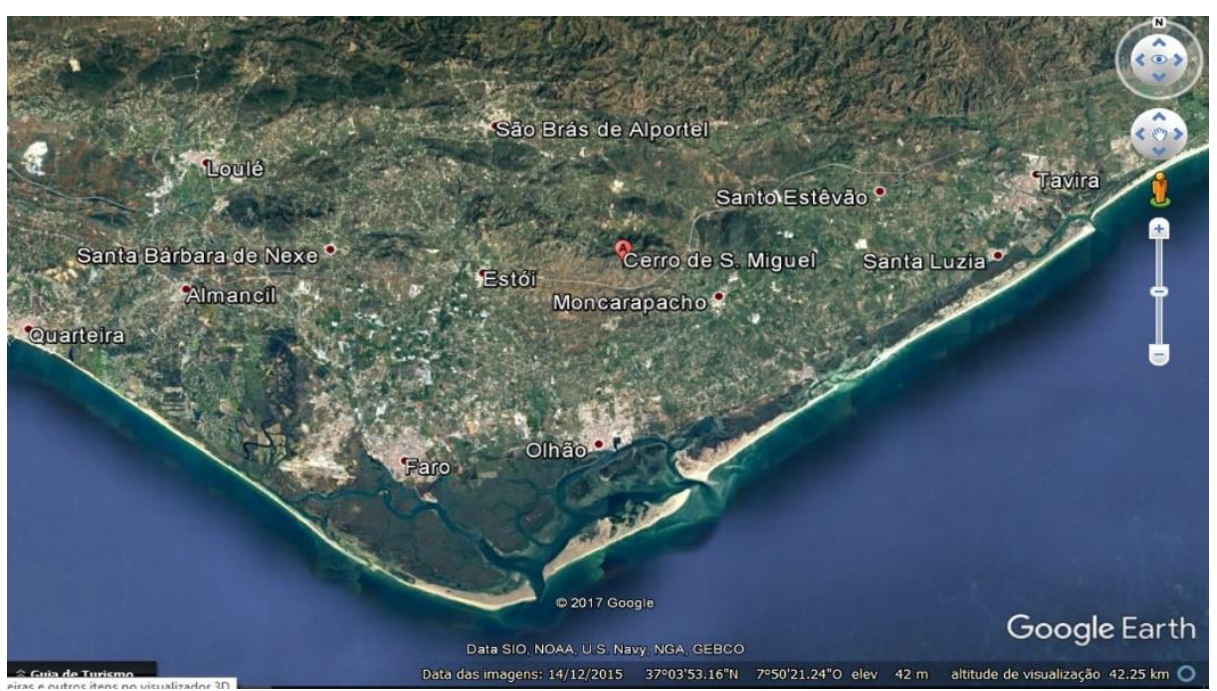

Fig. 2. Location of hill of S. Miguel, located northwest from Faro (Source: Google Earth, 2017)

\section{Characterization of the Walls in the Geographic Zone Under Study}

\subsection{Introduction}

The walls of the Algarvian barrocal have different characteristics from other parts of the country, especially in the area of the river Alva, or in the municipality of Sertã. In the first area referred to, there are already works with the aim of minimizing the fire risk [1] and, in the second zone, there are works of surveys and patrimonial valorization 
[3]. In both cases, the areas mentioned do not have problems of lack of water, due to its type of climate and geology, being the question of the forest fires more pressing; in the Algarvian barrocal, the problem is the lack of water and the erosion caused by the rains of torrent that usually happen in this region.

The main function of the existence of these walls is agriculture and, in the area under study, the main attributes characterizing the functions of the walls are the control of water erosion by controlling the floods and the consequent incentive to the water's infiltration in the soil, feeding the underground aquifers and wells, usually located near the habitations. The differentiation of the function of the walls is influenced by the geology and the climate that exist in the different regions of the country. In the case of the Algarve, the climate is of the Mediterranean type and in the barrocal the incidence is limestone, as said before, originating specific typologies and functions and differentiated from the rest of the Country.

The distribution of the walls' structures in the territory is not random, due to a relation between the physical characteristics of the terrain and the human performance, according to their needs [10].

In fact, the support and dividing walls form a structure of the territory [3,6], which makes it possible to identify both the settlements and the more arable areas, as well as the forest areas, due to the absence of these structures. Unfortunately, in many territories, there is a gradual replacement of drystone walls with masonry or concrete walls.

The conservation of water in the soil, a fundamental element for the survival of a society with apparently undeveloped technological resources, as is the case of the area under study, was largely ensured by the drystone wall structures that support the terraces and model landscape's backdrop that fits the urban-tourist concentration of the Algarve's coastline.

Indeed, in the Mediterranean landscapes which have been subject to successive deforestation for thousands of years, erosion control of the slopes and convoying of the run-offs, find in the terraces and hard-edged drystone walls, the best examples of the adaptation of society to the diversity of natural conditions [31].

In order to understand the nature of this landscape, it is important to take into account, firstly, the functions performed by the structure of drystone walls, particularly in their constructive characteristics and spatial distribution.

For the characterization of the walls that were found, the works of AA.VV. and of Rebelo $[1,10]$ are used, although the latter doesn't belong to the Mediterranean climate. However, both present ways of grouping the typologies were found in each study site and proceed with a cataloging of the same.

Although works about the structural dimensioning of drystone support walls are beginning to appear [32], its modeling is difficult, given the heterogeneity of the elements that form the same. According to the same author, the analysis has to be carried out in two stages: one, on a coarser scale, as one wall of gravity, monolithic and the other, on a more refined scale, as an element consisting of several different elements which have to work as a whole. 


\subsection{Characterization of the Walls}

Constructive processes. The rigging techniques vary depending on the type of stone found on the site, its function (division of property or land support) and the economy of the fields, giving rise to a huge variety of rigging and finishing of the walls.

A drystone wall is a wall that works by gravity, working it in our favor; however, the way stones are fitted and locked together is of enormous importance for the wall's stability.

For the wall to have quality, it is very important to choose the type of stone to use and to have some art in the way the stones are placed, forming almost a natural puzzle. For the success of the wall, that is, to perform the functions for which it was built, the experience of master masons is fundamental, which is a limitation for several reasons: masters are disappearing and have no apprentices to whom they could transmit their knowledge; this knowledge was transmitted orally and ascertained with practice, and therefore written records are scarce.

In order to construct a wall, one needs a proper equipment, mainly for the transport of the stones, which are usually heavy for a single person to handle.

Works begins on the demarcation of the wall, at the edge of the property, and it is necessary to confirm whether or not foundations are necessary: a low wall can be built directly on the ground, but generally, in the case under study, given its height, foundations are needed $[32,33]$. It is necessary to pay attention to the settlement suffered by the wall over time, due to its own weight. It is for this reason that, after a few years, one cannot tell the difference between a wall with and without foundations.

The drystone walls of property division can have several dimensions, however, Antão [34] recommends that, in the Algarvian barrocal, they will be between 0.60$1.5 \mathrm{~m}$ wide by $0.60-1.20 \mathrm{~m}$ height.

When the function is the containment of lands, forming terraces, the walls are constituted only by an outer row, slightly inclined (Fig. 3), to compensate the pressure of the soil, with a filling with earth or small stone as the row grows. The consolidation of the filling layer is done over time, with the entrainment of debris (ibidem).

In the study area, it was verified that there are cases where the walls are more than $3 \mathrm{~m}$ high, which makes it a remarkable work of earth retaining wall, taking into account that it is in drystone.

It should be noted that, where a wall performs two functions at the same time, the limitation of ownership and earth retaining, the construction and maintenance of the wall are the responsibility of the owner of the land that is located at the upper bound [34], making this rule part of the Portuguese Law.

For the wall to be in squareness, a rope is used as a guide, maintaining the verticality with a plumb line. The worst stones are placed first, forming a "bed" and the rows should have a slight "back" in that "bed" [33].

The foundation rows should be higher on the outer faces than in the center, to allow a good drainage and for the outer faces of the structure to be supported against each other, helping to keep the wall standing up by pulling the stones down and to the interior of the wall (ibidem). 


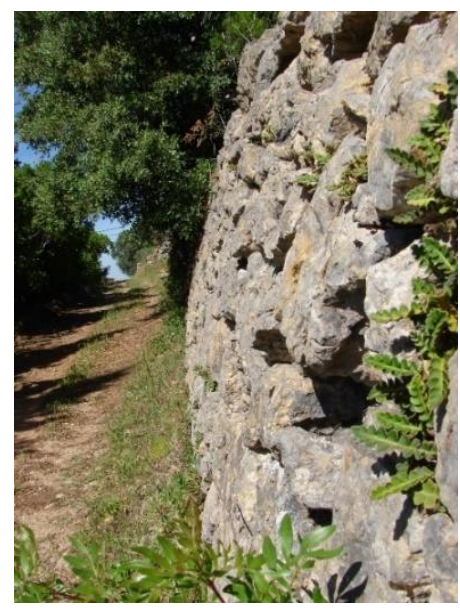

Fig. 3. Supporting wall in Algarvian barrocal, where one can observe the slope in the parament, to compensate the pressure of the terrain (Source: authors)

In the construction of the wall facing, the best sides of the stones should be chosen for the outside of the wall and a filler should be placed with stones of smaller granulometry between the outer faces (Fig. 4). The width of the wall is defined according to the height, which is directly proportional [34].

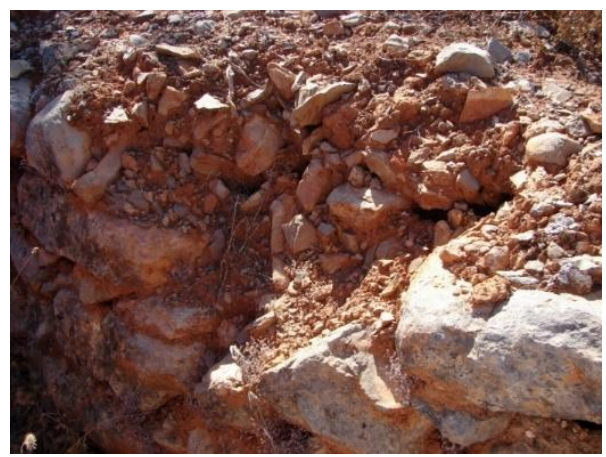

Fig. 4. Wall in the Algarvian barrocal, partially destroyed, where one can see the filler of the wall with stones of smaller granulometry (Source: authors)

To improve the stability of the wall, the "one on two" technique is often used, that is, the vertical seams should be avoided by placing one stone on two (Fig. 5). One should place a larger stone, with its greater side pointed to the interior of the wall, at regular intervals, to serve as a locking, improving the bracing.

Because they form the most vulnerable parts of the walls, the corners and edges are very important points, and therefore, the best pieces should be used there, paying special attention to their crossing (Fig. 6). 


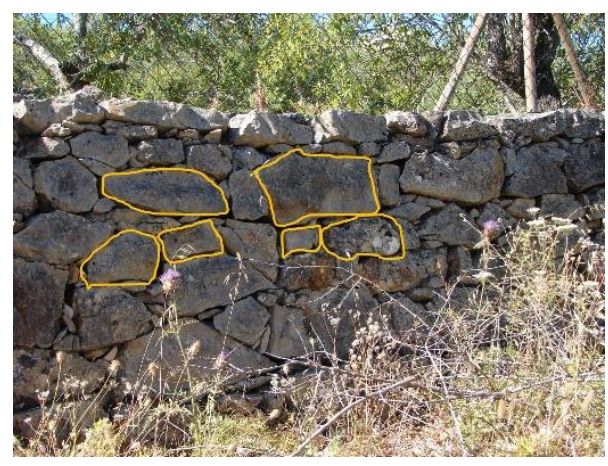

Fig. 5. Wall in the Algarvian barrocal, where one sees the technique "one on two" (Source: authors)
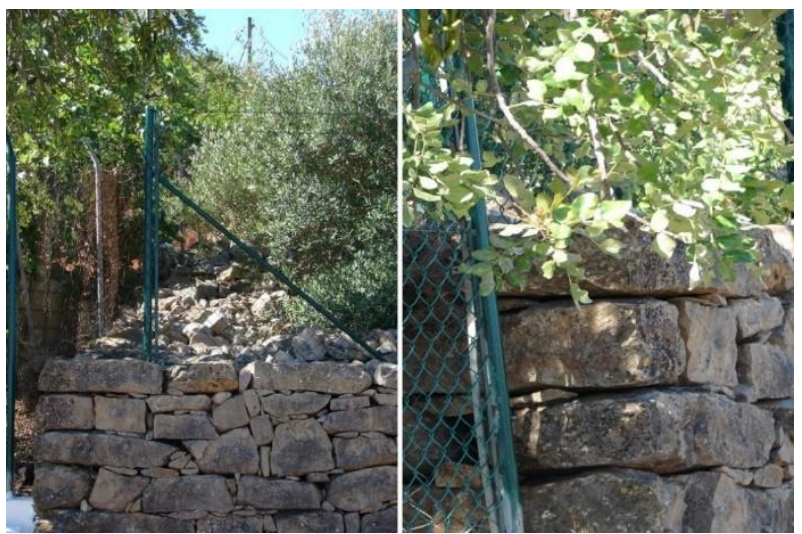

Fig. 6. Wall in the Algarvian barrocal (Source: authors)

In the previous figure it is represented, on the left: corner of the wall, where the cross layout of the larger stones, on the face, can be seen and, on the right: detail, where the cross of the stones in the corner can be seen.

In these walls, and in the case of the study area, drainage is very important for the durability of the wall, because water is accumulated against the faces of it, exerting a tension that increases with height. Thus, the wall must be prepared to withstand not only the impulses of the ground, but also the pressure of the water.

Typologies. The architecture of the walls, in addition to the construction technique itself, within the framework of the soil mechanics, has many elements associated with it, with the function of supporting the agricultural activity, such as: the way in which access to the terraces is made; the gates; the finishing of the walls; the systems of flood control. All these details are identifiers of the various geographical areas, and should be characterized and inventoried, grouping into typologies. 
For a question of systematization, it was a concern to group the typologies found, depending on the structural disposal, type of rigging, type of crowning, type of access to terraces and flood regularization systems.

Structural Disposal. Several forms of structural disposal of terraces fields have been found (Fig. 7), such as those designated as "continuous parallel" [1, 10], "zigzag" (ibidem), "concentric" (ibidem), "radial" [1], "orthogonal" (ibidem) and, a different case, which we will call "right-angled". In this case, the main function is to limit the property, presenting a slightly concave arrangement with respect to the slope, forming a right angle at its highest point.

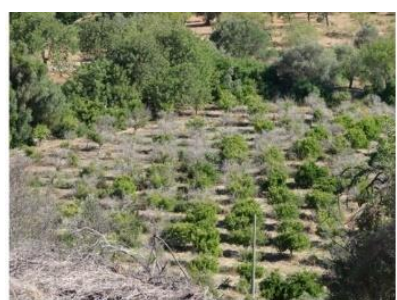

Continuous parallel

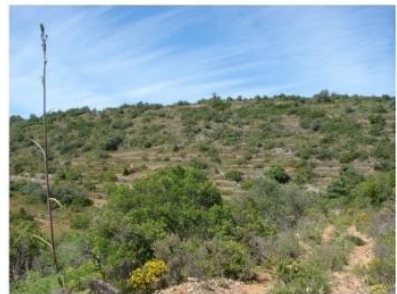

Concentric

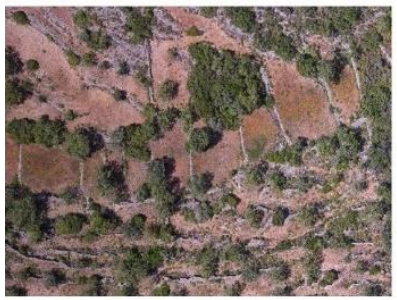

Orthogonal

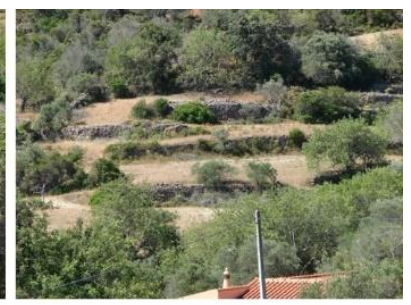

Zig-Zag

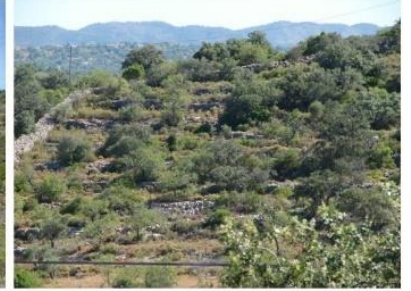

Radial

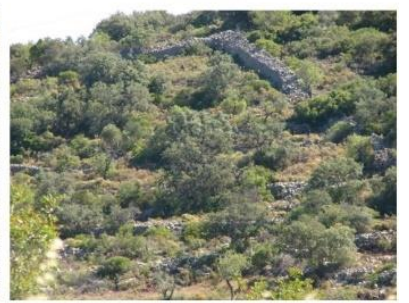

Right-angled

Fig. 7. Types of structural disposal of drystone walls in the Algarvian barrocal (Source: authors)

Rigging. There have also been various forms of rigging, such as those designated "without rigging or irregular" [1, 10], "crossed rigging" [1], "with some rigging" (ibidem) and "with irregular rigging" $[1,10]-$ Fig. 8.

However, new constructions of walls have been recorded, which do not respect the scaling of the traditional stones used, probably due to issues of constructive urgency. In this case, the stones already arrive carved to the place and have enormous dimensions 
in relation to the in situ existing rocks (Fig. 9). In spite of being another interpretation of the traditional walls, the function of cleaning the fields of the stones, was lost.

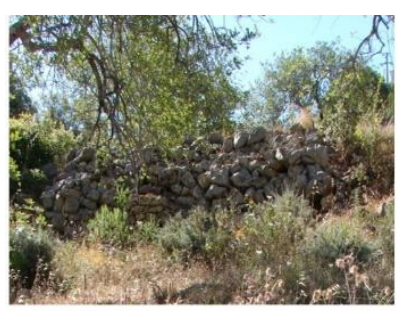

Without rigging or irregular

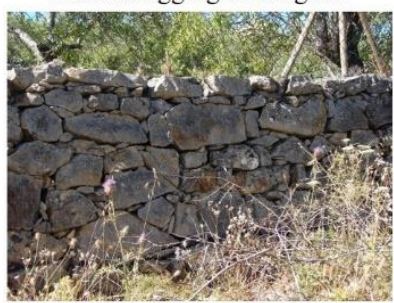

With some rigging

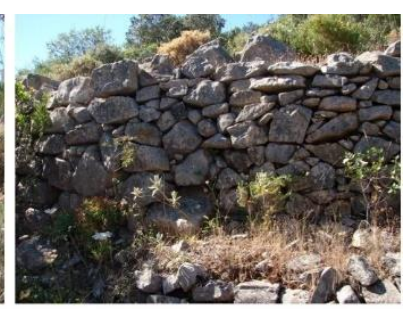

Crossed rigging

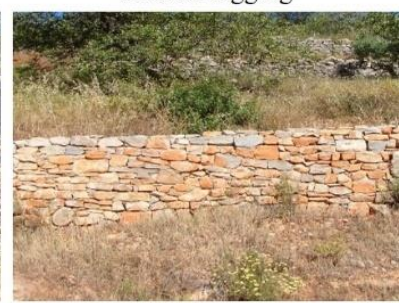

With irregular rigging

Fig. 8. Types of drystone walls' rigging in the Algarvian barrocal (Source: authors)

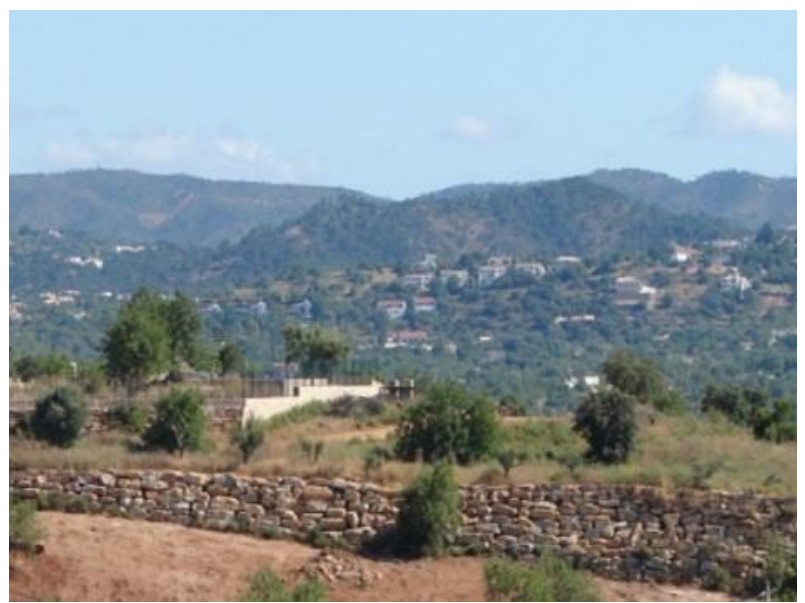

Fig. 9. New walls using stones with very large dimensions (Source: authors)

Crowning. In most cases of the terraced walls of the area under study, there is no special crowning or finishing, most of which are "without crowning", "leveled crowning" [1, 10] and also appear "raised crowning" cases [1]. The walls that limit the roads, especially in the immediate vicinity of the dwellings, are more careful works in their coat and decoration, often with plastered and painted walls, with decorative trim on the crown (Fig. 10). 
Access. General access to the terraces is made by "ramp" $[1,10]$, and no other type of devices have been found (Fig. 11).

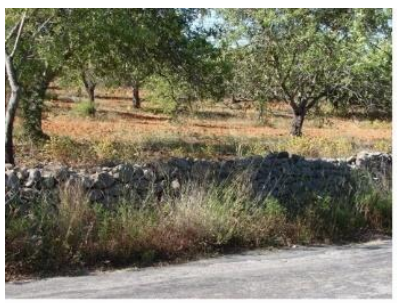

Without crowning

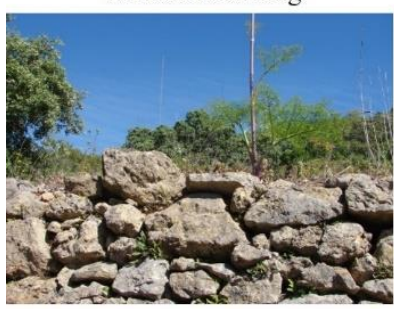

Raised crowning

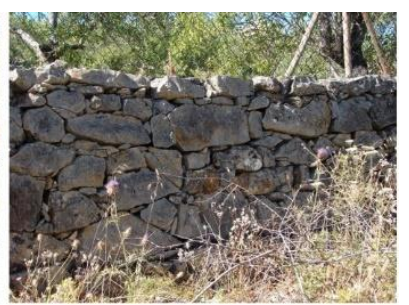

Leveled crowning

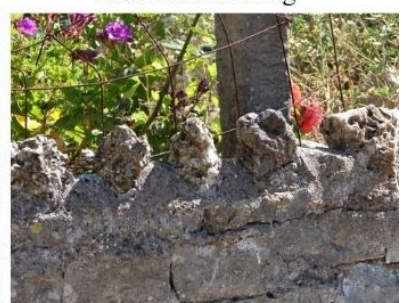

Decorative trim on crown

Fig. 10. Types of drystone walls' crowning in the Algarvian barrocal (Source: authors)

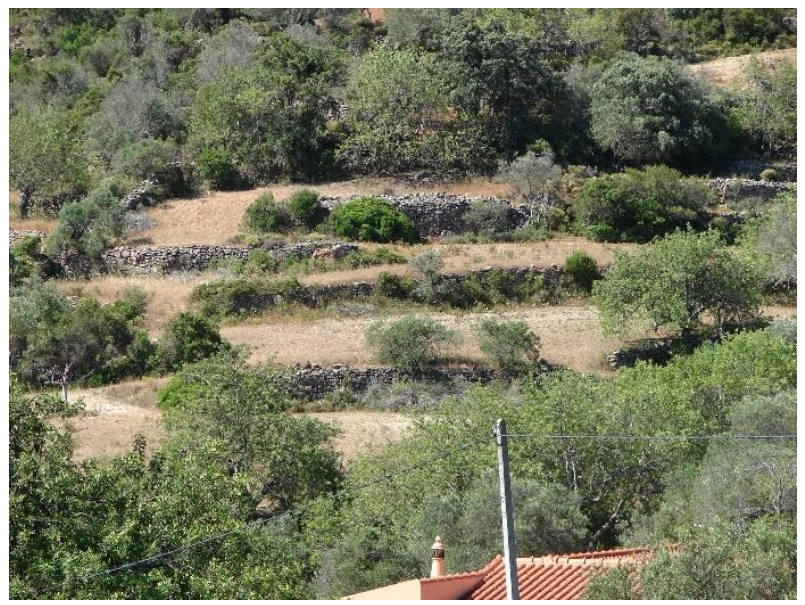

Fig. 11. Types of drystone walls' access in the Algarvian barrocal (Source: authors)

Flood regularization systems. Several hydraulic systems have been detected to regulate the flood, among which are elements such as "channel between walls" [10], "u-shaped retention ponds or albarrada system" (ibidem), coinciding with walls disposed in zigzag, and "cesspool" (ibidem) - Fig. 12.

However, in addition to these isolated elements, an integrated system was observed that serves to mitigate erosion and, simultaneously, to increase water infiltration in the soil and to transport and/or retain sediments on the terraces. 


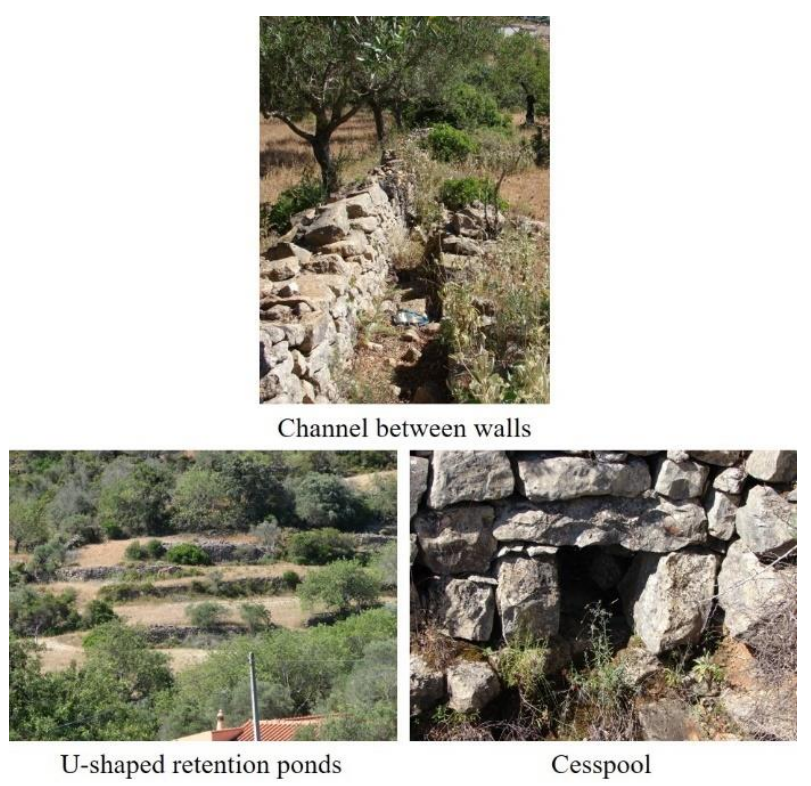

Fig. 12. Types of drystone walls' flood regularization systems in the Algarvian barrocal (Source: authors)

The terraces feature a slope that converges to the base of the wall, where a collector system exists, similar to micro ditches, also collecting water from the walls' drainage. The wall system works as a real sewage network [31].

In the pilot zone, we carried out a photogrammetric survey that illustrates many of the considerations and schemes exposed in publications about this theme in several areas of the Mediterranean. The topography was analyzed applying Structure-from-Motion and Multi-View-Stereo to images with $80 \%$ overlap taken from an unmanned-aerial-vehicle flying 60 meters above mean ground-height. This stereo-photogrammetry nearly automated compilation of digital imagery processing strategies allowed both solving camera positions and acquiring massive geometric data for surface reconstruction through a dense point-cloud and a digital-elevation-model [35-37]. Surface reconstruction and camera positions were then required to correct the radial displacement of each pixel characteristic in a central-projection of the photographic images that will form the orthographic-mosaic.

Fig. 13 shows the adaptation of the terraces to the topographic conditions, although the shrub vegetation does not allow a clearer reading of the drainage. In any case, and despite the abandonment of many of the agricultural parcels, the structure of drystone walls remains due to subsistence activities which, however, are still insufficient to cope with increasing degradation affecting the protection functions that these walls play.

In the example of Fig. 13-a, it can be observed that, in the southernmost slope, where the slope is more accentuated (Fig. 13-b), stone walls were constructed with smaller spacing between them, almost parallel to the level curves (Fig. 13-c), while on the northern slope the wall spacing is higher. In any case, they are crossed by other walls, 
perpendicular to the level lines, which serve as draining layers, guiding the floodplain (full dash in Fig. 13-d), and directing the water to trenches and ravines [31].
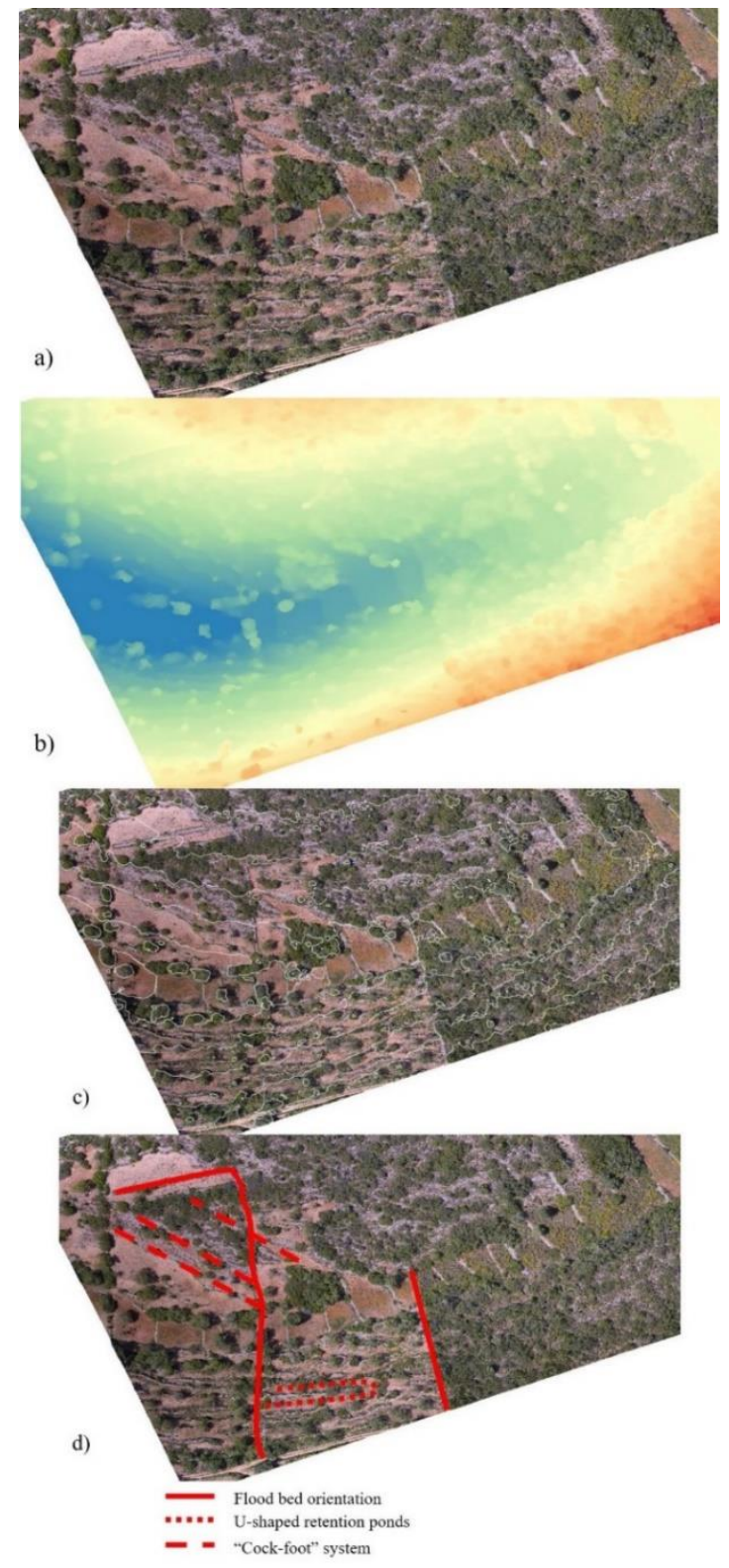

Fig. 13. Pilot zone of the Algarvian barrocal: a) orthophotomap; b) hypsometric map; c) orthophotomap with level lines; d) scheme of the hydraulic system (Source: authors) 
Drainages of the cultivation fields are also observed (broad dashed in Fig. 13-d), using the form of "cock's feet", converting the water to the walls that cross them perpendicularly. Taking advantage of the ramp access, the walls make u-shaped retention ponds structures, forming zig-zag and breaking the speed of the water (dashed line in Fig. 13d).

This whole structure converges to the valley, where there are walls perpendicular to the axis, forming stairs similar to the sloping terraces, helping the sediments to settle. The objectives are to reduce water velocity, reduce water erosion, and compel water to seep into the soil, while depositing debris, thus achieving more fertile areas for agriculture by humidity retaining.

\section{Conclusions}

The landscapes of walls are an excellent representation of nature that has been modified by man, expressing the history and culture of the people of these places. They can be interpreted as evocative and inspiring places, creators of opportunities and modernity, offering economic and tourist opportunities that can be used to revive and renew them. Their future can be plural and efficient, allowing the coexistence of new activities and agricultural work, while establishing alternative uses that help to ensure their own survival [6].

Drystone heritage is so important and expressive of the Mediterranean culture that in 2004 the Torroella de Montgrí Declaration was drawn up to defend the cultural heritage of the drystone in Baix Empordà (Catalonia, Spain), where a coordinating entity was created to protect this type of heritage in the Catalan countries and to encourage the exchange and networking between transnational structures with similar aims [38].

For this reason, in the development of this work, we intend to carry out a detailed and exhaustive inventory of assets, both for subsequent consultation and for the preparation of cartography and scientific production, as it has been successfully carried out elsewhere.

From the adaptation to the topography, a whole articulated network characterizes the territory, in a variety of ways, in which the predominant developments are approximately parallel to the level lines, intersected by others of almost perpendicular development and of slightly different characteristics, articulating this network with other walls of property's division or paths' marking.

The perception of how the walls are arranged in the fields, how they are constructed and their main functions were described in this article. The perception and understanding of these factors are extremely important so that not only the tourists, but especially the local populations, will attribute cultural value to these constructions, with the aim of maintaining and caring for them.

The proposals presented here for reuse of these structures for the tourism sector are very important because they open a new perspective in these important sectors of the economy of the Algarve region. 
It seems to us that this theme has a great potential for a tourist exploitation, and at the same time, tourism is used as a mean of dissemination, encouraging the population to play an active role in the safeguard of this vernacular heritage.

\section{References}

1. Rebelo, F., Nave, A., Pereira, N., Silva, M., Carvalho, A., Fialho, J.: Paisagens de socalcos e riscos naturais em vales do Rio Alva. Núcleo de Investigação Científica de Incêndios Florestais, Faculdade de Letras da Universidade de Coimbra, Coimbra (2006)

2. Bragança, C., Gonçalves, M.: Building the landscape. Rehabilitation and renewal of traditional mediterranean structures. In: 41th IAHS World Congress on Housing., Albufeira (2016)

3. Gonçalves, M.M.: El conocimiento del patrimonio en cuanto factor de estructuración de la sostenibilidad de los territorios. El caso de la freguesia de Cernache do Bonjardim, Portugal, (2016)

4. Petronela, T.: The Importance of the Intangible Cultural Heritage in the Economy. Procedia Econ. Financ. 39 OP, 731-736 (2016). doi:10.1016/S2212-5671(16)30271-4

5. Villacis-Mejía, M.C., Torres-Matovelle, P., Pons-García, R.C., Tanda-García, J.: Diseño de productos turísticos culturales a partir del patrimonio inmaterial. 15, (2016)

6. Bellmunt i Chiva, J., Sogbe Mora, E.: El paisatge de la paret seca. In: La pedra seca. Evolució, arquitectura i restauració. pp. 111-145. BRAU Edicions (2010)

7. Colomar-Mari, A.: Restauro dos muros de pedra seca e dos socalcos cultiváveis. Serra de Tramuntana (Baleares, Espanha), (1997)

8. Projecto HERCULE, http://www.ladpm.pt/projectos/index.php?tmpl=tmpl_projectos_hercule

9. AA.VV.: Marjades i prevenció de riscs naturals. TERRISC. Consell de Mallorca (2007)

10. AA.VV.: Patrimoni de marjades a la mediterrània occidental. Una proposta de catalogació. PATTER. Consell de Mallorca (2002)

11. Projecto PATTER, http://www.conselldemallorca.net/media/22992/PATTER_baixa_res.pdf

12. Interreg project ALPTER, http://alpter.net/

13. Progetto LIFE 00 ENV/IT/000191 PROSIT, http://www.parconazionale5terre.it/pagina.php?id=7

14. Oliveira, E., Manso, P.: Turismo sustentável: dimensões sociais e ambientais. In: 17o Congresso da APDR e 5o Congresso de Gestão e Conservação da Natureza, Congresso Internacional da APDR/AECR. pp. 626-634. APDR, Bragança-Zamora (2011)

15. PORDATA: Receitas de alojamentos turísticos por municípios, http://www.pordata.pt/Municipios/Proveitos+totais+dos+estabelecimentos+hoteleiros+total+e+por+tipo+de+estabelecimento-769

16. Medeiros Gouvêa, A.: Algarve: Aspectos fisiográficos. Author Edition, Lisboa (1938)

17. Lautensach, H.: Portugal. Auf Grund eigener Reisen und der Literatur, Band. 2: Die Portugiesischen Landschaften. Perthes, Gotha (1937)

18. Bragança, C., Gonçalves, M., Prates, G.: Estruturas mediterrânicas tradicionais. A utopia da paisagem urbano-turística do Algarve. In: I Colóquio Ibérico da Paisagem. , Lisboa (2016)

19. Feio, M.: Le Bas Alentejo et l'Algarve. Centro de Ecologia Aplicada da Universidade de Évora, Évora (1983) 
20. Rosendahl, S.: Die oberjurassische Korallenfazies von Algarve (Südportugal). Arb. Inst. Geol. Paläont. Univ. Stuttgart. N. F. 82, 1-125 (1985)

21. Costa, J.B.M. p. A.S.F.: Carta hidrolgeológica da orla algarvia. , Lisboa (1985)

22. Serra, G.G.: Pesquisa em arquitectura e urbanismo: um guia prático para o trabalho de pesquisadores em pós-graduação. Editora Mandarim EDUSP, São Paulo (2006)

23. Galindo González, J., Sabaté Bel, J.: El valor estructurante del patrimonio en la transformación del territorio. Apuntes. 22, 20-33 (2009)

24. Vecco, M.: A definition of cultural heritage: from the tangible to the intangible. J. Cult. Herit. 11, 321-324 (2010)

25. Silva Pérez, R.: Hacia una valoración patrimonial de la agricultura. Scr. Nova, Rev. Electrónica Geogr. y Ciencias Soc. XII, (2008)

26. ICOMOS: Australia ICOMOS Burra Charter. (1999)

27. ICOMOS: Carta do Património Vernáculo Construído. (1999)

28. Conselho da Europa: Convenção de Faro sobre o valor do património cultural para a sociedade. (2005)

29. Carvalho, F.M.L. de: Muros de pedra no desenho da paisagem terceirense e presença na arquitectura contemporânea, (2008)

30. Châtelain, A.: Patrimoine rural. Reflet des terroirs. REMPART (2009)

31. Larcena, D.: Terrasses et eau des versants en Méditerranée. Dynamiques écologiques et économiques. In: De l'eau agricole à l'eau environnementale. Résistence et adaptation aux noveaux enjeux de partage de l'eau en Méditerranée. pp. 241-252. Éditions Quae (2012)

32. Colas, A.-S.: Mécanique des murs de soutènement en pierre sèche: modélisation par le calcul à la rupture et expérimentation échelle 1, (2009)

33. Vivian, J.: Como construir muros de pedra no jardim, na horta, na quinta. Europa América (2011)

34. Antão, T.F.L.: O espaço de habitar vernacular no Barrocal Algarvio, (2010)

35. Furukawa, Y., Ponce, J.: Accurate, dense, and robust multi-view stereopsis. In: IEEE Conference on Computer Vision and Pattern Recognition (CVPR). pp. 1-8. , Minneapolis, USA (2007)

36. Snavely, N., Seitz, S.N., Szeliski, R.: Modelling the world from internet photo collections. Int. J. Comput. Vis. 80, 189-210 (2008)

37. Westoby, M.J., Brasington, J., Glasser, N.F., Hambrey, M.J., Reynolds, J.M.: "Structurefrom-Motion" photoggrammetry: a low-cost, effective tool for geoscience applications. Geomorphology. 179, 300-314 (2012)

38. Declaració de Torroella de Montgrí per a la defesa del patrimoni cultural de la pedra en sec. , Baix Empordà, Catalunya, Spain (2004) 